\title{
Az élelemhez való jog koncepciója a nemzetközi jogban
}

\author{
élelemhez való jog - emberi jogok nemzetközi védelme - nemzetközi jog - \\ gazdasági, szociális és kulturális jogok érvényesithetősége
}

\begin{abstract}
Az alapvető emberi szükségletek biztosítása fontos elöfeltétele a legfontosabb emberi jogok, így többek között az élethez és emberi méltósághoz való jog érvényesítésének. Ezen emberi szükségletek közül is kiemelkedik az emberek élelem- és ivóvízszükségletének biztosítása, melyek nélkül nehezen képzelhető el nemcsak az emberhez méltó élet, de egyáltalán bármilyen élet fenntartása. A vízhez való jog alapkérdéseivel kapcsolatosan számos tanulmány érhető el már magyar nyelven is, ${ }^{1}$ azonban az élelemhez való jog mind ez ideig talán kevésbé került Magyarországon a vizsgálódások középpontjába. ${ }^{2} \mathrm{~A}$ kérdés fontosságát jól mutatja ugyanakkor, hogy az ENSZ Élelmezésügyi és Mezőgazdasági Világszervezete (FAO) 2012. évi statisztikája szerint világszerte mintegy 868 millió ember (a Föld népességének 12\%-a) éhezik vagy alultáplált, döntő többségük a szubszaharai és az ázsiai régióban, ${ }^{3}$ ami sokkal inkább a helyzet változatlanságát, mintsem annak javulását mutatja. ${ }^{4}$ Annak
\end{abstract}

* Dr. Szemesi Sándor egyetemi docens, Debreceni Egyetem Állam- és Jogtudományi Kar, Európa Jogi és Nemzetközi Jogi Tanszék, szemesi.sandor@law.unideb.hu. A kutatás az Európai Unió és Magyarország támogatásával, az Európai Szociális Alap társfinanszírozásával a TÁMOP 4.2.4.A/2-11-1-2012-0001 azonositó számú „Nemzeti Kiválóság Program - Hazai hallgatói, illetve kutatói személyi támogatást biztosító rendszer kidolgozása és müködtetése konvergenciaprogram" című kiemelt projekt keretei között valósult meg. ${ }^{1}$ Például Kardos Gábor: A vízhez való jog. Acta Humana, 14. évf. (2004) 1. sz. 81-92; KARDos Gábor: Az élelemhez, illetve a vízhez való jog védelme az univerzális nemzetközi jogban. In: CsApó Zsuzsanna (szerk.): Ünnepi tanulmánykötet Bruhács János professor emeritus 70. születésnapjára. Pécs, 2009, 116126; KECSkÉs Gábor: A vízhez való jog nemzetközi koncepciója. Állam- és Jogtudomány, 50. évf. (2009) 4. sz. 569-598.; SzAPPAnYos Melinda: Víz és jog - A vízhez való jog érvényesíthetösége az ENSZ keretében. Veszprém, Veszprémi Humán Tudományokért Alapítvány, 2013; SzILÁGYI János Ede: Vízjog - aktuális kihívások a vizek jogi szabályozásában. Miskolci Egyetem, 2013.

2 A relatíve kevés kivételre lásd például TiBA Zoltán: $A z$ „éhezéshez való jog” a nemzetközi jogban. Acta Humana 13. évf. (2003) 3. sz. 47-53; Selmeczı Anna: Az éhezéselméleti diskurzus alakulása. Kül-Világ 2006. 3-4. sz. 21-39.

3 http://www.fao.org/hunger/en/; http://www.fao.org/fileadmin/templates/es/Hunger_Portal/webVersion.jpg (2013. október 28-i letöltés).

4 A 2007-2009 közötti időszakban a FAO kimutatásai szerint 869 millió fő minősült éhezőnek vagy alultápláltnak. A bekövetkezett, bőven statisztikai hibahatáron belüli (1 millió fö) változást legfeljebb a Föld növekvő népességéhez képest lehet javulásként értékelni, megítélésem szerint. 
ellenére igaz ez, hogy az élelemhez való jog folyamatosan jelen van az ENSZ Emberi Jogi Tanácsának napirendjén. ${ }^{5}$

Az élelem egyenetlen eloszlása számos tényezö függvénye, melyek között akadnak az embertöl független környezeti (így különösen a Föld éghajlati adottságaiból adódó), embertől függő környezeti tényezők (értve ez alatt különösen a klímaváltozás hatásait, illetőleg a bioüzemanyag előállítása által okozott élelmiszerhiányt $\left.{ }^{6}\right)$ és közvetlenül az emberi magatartásra visszavezethető, a környezeti kérdésektöl teljesen független tényezők (polgárháborús övezetekben, egyéb fegyveres konfliktusokkal sújtott, illetőleg politikailag bizonytalan térségekben a befektetések hiánya és azok következményei, a gazdasági válság hatásaiból adódóan növekvő élelmiszerárak, egyes fejlett államok protekcionista agrárpolitikája) egyaránt.

Jelen tanulmány keretei között azt kívánom bemutatni, hogy létezik-e (létezhet-e) jog az élelemhez, és ha igen, mi is pontosan eme jog tartalma, és lehetséges-e annak bármilyen formában történő kikényszerítése. Nem kívánok ugyanakkor részletesebben foglalkozni azon, nem közvetlenül emberi jogi tárgyú nemzetközi jogi intézményekkel és mechanizmusokkal, melyek az élelemhez való joggal kapcsolatba hozhatóak (értve ez alatt többek között az Európai Unió mezőgazdasági politikájának vagy éppen a WTO vitarendezési eljárásának az élelemhez való joggal meglevő, esetleges kapcsolódási pontjait), hiszen ezek túlfeszítenék jelen, elsősorban emberi jogi megközelítést alkalmazó írás kereteit.

\section{Az élelemhez való jog - nemzetközi jogi alapdokumentumok}

Az élelemhez való jog, mint alapvető emberi jog, csak az 1948-ban elfogadott Emberi Jogok Egyetemes Nyilatkozatával került elismerésre, a megfelelő életszínvonalhoz való jog szelvényjogaként (részjogaként). Az Egyetemes Nyilatkozat 25. cikk (1) bekezdése értelmében „[M]inden személynek joga van saját maga és családja egészségének és jólétének biztosítására alkalmas életszínvonalhoz, nevezetesen élelemhez..." A jog tartalmát az 1966-ban elfogadott Gazdasági, Szociális és Kulturális Jogok Nemzetközi Egyezségokmánya 11. cikke bontja ki részletesen, megkülönböztetve az élelemhez való jogot és az éhezéstöl való mentesség jogát mint ugyanazon jogosultság pozitív és negatív oldalait, továbbá a nemzeti kormányok és a nemzetközi közösség feladatává teszi, hogy azok biztosítsák a világ élelmiszer-

5 Legutóbb lásd: The Right to Food. Resolution adopted by the Human Rights Council on 9 April 2013, A/HRC/ RES/22/9.

6 Egyes kimutatások szerint 50 liter, azaz nagyjából egy tank bioüzemanyag előállitásához nagyságrendileg 200 kg kukoricára van szükség, ami egy ember egész éves élelmiszer-szükségleteit is képes (lenne) fedezni. Ráadásul a bioüzemanyag előállitásával csökken az élelemtermelésre rendelkezésre álló termőterület is, ami pedig mezőgazdasági áremelkedést idézhet elö. Bővebben lásd MAHON, Claire: The Right to Food: a Right to Everyone. In: Rosin, Christopher-Stock, Paul-CAmpBell, Hugh (eds.): Food Systems Failure: The Global Food Crisis and the Future of Agriculture. Oxford, 2011. A kérdésröl bővebben lásd: CLoots, Ann Sofie: Biofuels and the Right to Food: an Uneasy Partnership. In: DE SchutTer, Olivier-Cordes, Kaitlin Y (eds.): Accounting for Hunger. The Right to Food in the Era of Globalisation. Hart Publishing, 2011, 95-134.

Létezik a szakirodalomban olyan álláspont is, mely a kettő között nem tesz különbséget. Lásd például: UN Committee on ESCR, E/C.12/1989/SR.20 (Discussion of Asbjorn Eide's Report), 26. 
készletének méltányos és a szükségleteknek megfelelő elosztását. Érdemes megemlíteni, hogy az Egyezségokmány szövegezésekor az eredeti javaslatban nem szerepelt az élelemhez (és ruházkodáshoz) való jogra való utalás, azt csak a kínai delegátus javaslatára emelték be a 11. cikk szövegébe. A kínai javaslat indokolása szerint a kevésbé fejlett államokban az élelem és ruházkodás szükségletei előbbre valóak, mint a javaslatban már eredetileg is szereplő lakhatáshoz való jog. ${ }^{8} A$ „,megfelelő" élelemre történő utalás pedig csak a szövegezés egy későbbi fázisában került a szövegtervezeten átvezetésre, jelezvén, hogy annak minden esetben el kell érnie egy bizonyos szintet. ${ }^{9}$ Az Egyezségokmányhoz kapcsolódó, 2008. december 10-én elfogadott és a közelmúltban, 2013. május 5-én hatályba lépett kiegészítő jegyzőkönyv pedig az egyének vagy csoportok számára is lehetővé teszi panasz benyújtását az Egyezségokmányban foglalt jogok, így az élelemhez való jog megsértésének valószínűsítése esetén a jegyzőkönyvben részes államokkal szemben. ${ }^{10}$

Egyes nemzetközi egyezmények az államok számára további, az Egyezségokmány általános előírásaihoz képest speciális, csak egyes csoportokra vonatkozó szabályokat is rögzítenek, melyek az általános védelmi szint megtartása mellett ezen csoportok fokozott védelmét hivatottak biztosítani. Explicit módon tartalmazza a megfelelő élelmezés biztosításának kötelezettségét a nők számára a terhesség és szoptatás idejére a nőkkel szembeni megkülönböztetés minden formájának felszámolásáról 1979-ben elfogadott New York-i egyezmény, valamint a tápláló élelmiszer és ivóvíz szolgáltatásának kötelezettségét, mint a rosszul tápláltság elleni küzdelem egyik eszközét a gyermek jogairól szóló 1989. évi New York-i egyezmény. A fogyatékossággal élő személyek jogairól szóló 2006. évi egyezmény a megfelelő életminőséghez való jog részeként említi a megfelelő élelem biztosítását, és a részes államok e jog érvényesülését bármiféle fogyatékosságon alapuló hátrányos megkülönböztetéstől mentesen kötelesek védeni és támogatni. A polgári lakosság számára a megfelelő élelemhez való jogot (a létfenntartáshoz nélkülözhetetlen javak részeként) mind nemzetközi, mind pedig nem nemzetközi fegyveres összeütközés esetén biztosítani kell, az 1977. évi genfi I. és II. kiegészítő jegyzőkönyvek értelmében. A népirtás büntettének megelőzése és megbüntetése tárgyában 1948-ban kelt nemzetközi egyezmény értelmében pedig akár népirtásként is értékelhető egy nemzeti, népi, faji vagy vallási csoportra olyan életfeltételek ráerőszakolása, melyek célja a csoport teljes vagy részleges fizikai elpusztulásának előidézése - mely elkövetési magatartásba a lakosság élelemtől való megfosztása is beletartozhat. ${ }^{11}$

8 UN Doc. E/CN.4/L.57, 14 UN ESCOR, CN.4 (1952).

9 Részletesen lásd: Craven, Matthew C. R.: The International Covenant on Economic, Social and Cultural Rights. A Perspective on its Development. Oxford, Clarendon Press, 1995, 291.

10 A 2013. október 28-i állapot szerint a kiegészítő jegyzőkönyvnek 11 részes (Argentína, Bolívia, BoszniaHercegovina, Ecuador, El Salvador, Mongólia, Montenegró, Portugália, Szlovákia, Spanyolország és Uruguay) és további 34 aláíró állama van, melyek között Magyarország nem szerepel. Forrás: http://treaties. un.org/Pages/ViewDetails.aspx?src=TREATY\&mtdsg_no=IV-3-a\&chapter=4\&lang=en (2013. október 28-i letöltés).

11 Így például a Nemzetközi Büntetőbíróság 1998-ban elfogadott Római Statútuma 7. cikk (1) bekezdés b) pontja és 7. cikk (2) bekezdés b) pontja szerint. 


\section{Az élelemhez való jog fogalmi kérdései}

Az élelemhez való jog fogalmi kérdéseinek vizsgálatakor elöljáróban célszerü azt rögzíteni, hogy az élelem és az élelmiszer eltérő fogalmi kategóriák, melyek egymással a „több és kevesebb” viszonyában állnak. Amíg az élelem az élethez szükséges elemi táplálékokat, feldolgozatlan élelmiszereket jelenti, melyek az egyén létfenntartásához szükséges ásványi anyagokat, vitaminokat és tápanyagokat tartalmazzák, ${ }^{12}$ addig élelmiszernek minden olyan feldolgozott, részben feldolgozott vagy feldolgozatlan anyagot vagy terméket tekinthetünk, amelyet emberi fogyasztásra szánnak, illetve amelyet várhatóan emberek fogyasztanak el. ${ }^{13} \mathrm{~A}$ már említett nemzetközi egyezmények a két fogalom közül kivétel nélkül az élelemhez való jogot deklarálják - méghozzá számos esetben a „megfelelő” élelem követelményével kiegészítve.

Az élelemhez való joggal (pontosabban annak sérelmével) összefüggésben lényeges különbséget kell tenni a mennyiségi értelemben és a minőségi értelemben vett éhezés között. Amíg elöbbi - elsősorban a szubszaharai térséget és Ázsiát érintő esetben az elfogyasztott táplálék a szervezet napi szükségleteit sem fedezi, és ekként közvetlen életveszélyt vagy akár halált okozhat, addig az utóbbi, globális problémát jelentő esetben az egyoldalú, szegényes táplálkozás fejlődési rendellenességek, betegségek okozója lehet, anélkül azonban, hogy az éhezés miatt közvetlen életveszély állna fenn. A mennyiségi értelemben vett éhezésen belül is különbséget tehetünk a hirtelen, valamilyen katasztrófa miatt bekövetkező akut éhínség (mely a mennyiségi értelemben vett éhezés mintegy $10 \%$-át jelenti) és a krónikus (hosszabb időn keresztül tartósan fennálló) éhezés között. ${ }^{14}$ Szakirodalmi álláspontok szerint az élelemhez való jog sérelméröl csak ezen utóbbi esetekben beszélhetünk, míg a minőségi (vagy más néven rejtett) éhezés más jogok (így például a testi és lelki egészséghez való jog) sérelmét valószínűsítheti. Érdekes megemlíteni, hogy létezik olyan szakirodalmi álláspont is, miszerint a mennyiségi értelemben vett éhezés demokratikus berendezkedésü államokban nem fordulhat elö, az a diktatúrák sajátossága csupán. ${ }^{15}$ És bár ebben a formájában ez a kijelentés aligha állja meg a helyét, ${ }^{16}$ az kétségtelen, hogy a történelem legnagyobb éhínségei mind feudális berendezkedésű vagy éppen diktatórikus államokban következtek be, melyek előidézésében többnyire az adott állam kormányát terheli elsődlegesen a felelősség. ${ }^{17}$

A megfelelő élelemhez való jogot el kell határolnunk az élelembiztonságtól, melyröl akkor beszélhetünk, ha egy adott területen élő minden személy bármikor képes

12 Kovács Júlia: Megvéd-e a jog az éhenhalástól - avagy megvalósulhat-e az élelemhez való jog a XXI. században? De iurisprudentia et iure publico, 2011. 4. sz. 5.

13 Lásd az Európai Parlament és a Tanács 178/2002/EK rendelete (2002. január 28.) 2. cikk.

14 Destaw Yigzaw: Hunger and the Law: Rethinking the Right to Food, 8. http://papers.ssrn.com/sol3/papers. cfm?abstract_id=1962391 (2013. október 28-i letöltés).

15 SEN, Amartya: Development as Freedom. Oxford University Press, 1999, 51.

16 Különösen „fiatal demokráciák” esetében fordulhat elő gyakran mennyiségi értelemben vett éhezés, melyre példaként hozható a 2005-ös nigeri éhínség, melynek fő okai a világ egyik legszegényebb, ámde 1999 óta demokratikus berendezkedésủ országát sújtó szárazság és sáskajárás voltak. Lásd például: Az Európai Parlament állásfoglalása a nigeri éhínségröl (2005. szeptember 28.). P6 TA(2005)0338.

17 Lásd például Marcus, David: Famine Crimes in International Law. The American Journal of International Law, Vol. 97. (2003) 2. sz. 250. 
fizikai és gazdasági értelemben is hozzáférni a számára megfelelő mennyiségü, biztonságos és tápláló ételhez, amely számára egy aktív és egészséges életmód folytatásához szükséges. Az élelembiztonság ekként tehát kifejezetten az élelemhez történő hozzáférés lehetőségét jelenti, ily módon előfeltétele a megfelelő élelemhez való jog teljes élvezetének. ${ }^{18}$ Miként az élelem és élelmiszer fogalma sem azonos, úgy az élelembiztonság sem azonosítható az élelmiszerbiztonsággal, ami az élelmiszerek szigorú minőségi követelményeknek való megfelelését jelenti. ${ }^{19}$ Élelmiszerfüggetlenségröl pedig akkor beszélhetünk, ha az emberek meghatározott csoportja (adott esetben akár az egész állam) képes a számára szükséges élelemmennyiség elóállítására - mely sokkal inkább az állami szuverenitás elvének gyakorlati megvalósulását jelenti, mintsem emberi jogi kérdések felvetését. Az élelmiszer-függetlenséghez való jogot több, döntően latin-amerikai állam (így például Bolívia, Ecuador és Venezuela) alkotmánya is tartalmazza, ${ }^{20}$ azonban álláspontom szerint nem jelenthető ki, hogy jelenleg ezen jogosultság (akár csak mint az állami szuverenitás elvének egyik fontos alkotóeleme) létezése tekintetében konszenzus volna a nemzetközi jogon belül.

\section{Az élelemhez való jog tartalma}

Az élelemhez való jog tartalmát az ENSZ Gazdasági, Szociális és Kulturális Jogok Bizottsága által elfogadott 12. számú Általános Kommentár (General Comment No. 12.) egyértelműsítette. A megfelelö élelemhez való jog akkor kerül biztosításra, ha minden férfi, nő és gyermek egyedül vagy egy közösségben fizikai és gazdasági értelemben is bármikor hozzáférhet a számára szükséges élelmiszerhez vagy ételhez. ${ }^{21} \mathrm{Az}$ élelemhez való jog tehát nem értelmezhető megszorítóan, és pusztán a megfelelő mennyiségủ kalória bevitelének biztosítása még nem jelenti a megfelelő élelemhez való jog biztosítását. Az élelem ugyanis csak akkor tekinthető megfelelönek, ha az étrend összességében megfelelő az adott személy mentális és fizikai fejlődéséhez (figyelemmel például a nemi és életkori sajátosságokra), mentes a káros adalékanyagoktól (mely az élelemhez való jogot a már említett élelmiszerbiztonság kérdésével kapcsolja szorosan össze), tekintetbe veszi az egyes kulturális szokásokat és étrendeket, és végezetül, amennyiben az élelmiszer akár közvetlen termelés útján, akár megfelelő elosztórendszerek révén fizikai értelemben is elérhetővé válik mindenki számára. ${ }^{22}$

Különbséget kell tennünk ugyanakkor az elérhetőség és a (gazdasági és fizikai értelemben is használható) hozzáférhetőség fogalma között. Amíg az elérhetőség csupán az élelem megszerzése lehetőségének biztosítását jelenti, addig a gazdasá-

18 The Right to Adequate Food. UN Human Rights Fact Sheet No. 34. United Nations, Geneva, $2010,4$.

19 Lásd például az Európai Parlament és a Tanács 178/2002/EK rendeletét (2002. január 28.). Az élelem- és föleg élelmiszerstandardok kapcsán említést érdemel a WHO és a FAO által 1963-ban létrehozott Codex Alimentarius is. Bővebben lásd http://www.codexalimentarius.org/ (2013. október 28-i letöltés).

20 The Right to Adequate Food. UN Human Rights Fact Sheet No. 34. United Nations, Geneva, $2010,4$.

21 Lásd: General Comment No. 12 on The Right to Adequate Food (E/C.12/1999/5), 6. pont.

22 General Comment No. 12. 9-12. pontok. 
gi értelemben vett hozzáférhetőség a személy vagy háztartás pénzügyi helyzetének vizsgálatát helyezi a középpontba. Ekként az élelem gazdasági értelemben akkor hozzáférhető, ha a megfelelő élelem megvásárlása nem veszélyezteti az érintettek más alapvető szükségleteit. E vonatkozásban merül fel az állam részéről annak kötelezettsége, hogy a szociálisan rászoruló csoportok számára biztosítsa ezen jogokat. A fizikai értelemben vett hozzáférhetőség azt jelenti, hogy a megfelelő élelem mindenki számára rendelkezésre áll, ideértve különösen a gyermekeket, időseket, a fogyatékkal élőket és a betegeket. A természeti katasztrófák áldozatai és más különösen hátrányos helyzetben levő csoportok tekintetében az államok részéről különös figyelmet igényel ezen jog biztosítása. ${ }^{23}$

Az élelemhez való jog biztosítása vonatkozásában a 12. számú Általános Kommentár nyomán (lényegében a legtöbb emberi joghoz hasonlóan) megkülönböztethetjük az annak tiszteletben tartására (respect), a már megszerzett jogosultságok védelmére (protect) és az élelemhez való jog teljesítésére és előmozdítására (fulfil) vonatkozó kötelezettségeket.

A már elért jogvédelmi szint tiszteletben tartásának kötelezettsége (respect) értelmében egyetlen állam sem csökkentheti az élelemhez való hozzáférés már elért szintjét sem jogalkotással (például jóléti intézkedések felfüggesztésével és ezáltal egyes rászoruló csoportok anyagi helyzetének számottevő rontásával), sem pedig fizikai intézkedésekkel (például erőszakos áttelepítésekkel, különösen olyan népcsoportok esetében, amelyeknél a föld a mindennapi megélhetés nélkülözhetetlen eleme) ${ }^{24}$ Amíg elöbbire gyakorlatilag a Föld bármely pontján találhatunk példát, addig az utóbbi fizikai intézkedések elsősorban ott képzelhetőek el, ahol az átlagosnál lényegesen erősebb a hagyományok tiszteletén alapuló törzsi életforma szerepe a társadalomban (így például az afrikai kontinensen).

A már megszerzett jogok védelmének (protect) kötelezettsége értelmében az államnak védelemben kell részesítenie a személyek már létező élelemhez való hozzáférési lehetőségeit harmadik személyek támadásaival szemben (legyenek azok a szomszédok, munkáltatók vagy éppen a kérdéses térségben tevékenykedő üzleti vállalkozások), értve ez alatt nem csupán a fizikai erőszak eseteit, de az adott területen keresztülhaladó, nem feltétlenül szükséges infrastrukturális beruházásokat, a súlyosan környezetszennyező technológiák alkalmazását vagy éppen az egészségre ártalmas élelmiszerek forgalomba hozatalának megakadályozását is. A védelmi kötelezettséghez szorosan hozzátartozik, hogy az állam köteles megfelelő jogorvoslati mechanizmust biztosítani a feltételezett jogsértések áldozatai számára. ${ }^{25}$ Amíg azonban a tiszteletben tartási kötelezettség (a legjobb védelem elvéből, mint az emberi jogok nemzetközi védelmének egyik alapelvéből levezethető ${ }^{26}$ ) abszolút kötelezettségként is értelmezhető, addig a védelemben részesítési kötelezettségnél az

23 General Comment No. 12. 13. pont.

24 The Right to Food. UNGA A/56/210 on 23 July 2001, 27. pont.

25 The Right to Food. UNGA A/56/210 on 23 July 2001, 28. pont

26 A legjobb védelem elvére (és egyben az emberi jogok nemzetközi védelmének alapelveire) lásd például KARDOS Gábor: Üres kagylóhéj? A szociális jogok nemzetközi jogi védelmének egyes kérdései. Gondolat, 2003, 21-22. 
államnak adott esetben már lehetősége nyílhat az érintett és a harmadik személyek érdekei mérlegelésére is.

Az állam végezetül az élelemhez való hozzáférés előmozdítására (azaz pozitív intézkedések megtételére) is köteles (fulfil), ami azonban nem jelent az élelem mindenki számára történő biztosítására vonatkozó általános állami kötelezettséget. Fő szabály szerint az állam csupán az élelemhez való hozzáférés lehetőségét (facilitate) köteles biztosítani például a termőföldekre vonatkozó szabályozás megalkotásával, vagy éppen a kötelező legkisebb munkabér összegének előírásával és biztosításával, de ezen kötelezettség gyakorlati megvalósulásának tekinthető a Magyarországon is müködő iskolatejprogram is. ${ }^{27}$ Amennyiben azonban egyes személyek vagy társadalmi csoportok rajtuk kívül álló okokból képtelenek az önellátásukról gondoskodni (például egy természeti katasztrófa vagy polgárháborús helyzet miatt, vagy személyes szabadságuk állam általi elvonása esetén), az állam köteles számukra a szükséges élelmiszer fizikai értelemben vett biztosítására is (provide), így ebben az esetben az élelemhez való jog egyfajta alanyi jogként is értelmezhetővé válik. ${ }^{28}$

Említést érdemel, hogy a szakirodalomban találhatunk egy negyedik kötelezettségtípust is, nevezetesen az elismerési (recognise) kötelezettségét, melynek értelmében az egyes államok nem csupán jogosultak, hanem kifejezetten kötelesek volnának a legfontosabb, jelen esetben az élelemhez való jogot is rögzítő emberi jogi tárgyú nemzetközi szerződések megerősítésére. ${ }^{29}$ Álláspontom szerint ez a megközelítés nem csupán annak bizonytalan tartalma miatt (szinte lehetetlen pontosan meghatározni, hogy melyek a „legfontosabb” emberi jogi tárgyú nemzetközi szerződések, bár néhány esetben, így például az ebben a tanulmányban központi szerepet kapó Gazdasági, Szociális és Kulturális Jogok Egyezségokmánya esetében ez alappal vélelmezhető), hanem sokkal inkább az államok szuverén egyenlősége elvével ellentétes megközelítése miatt sem fogadható el a nemzetközi jogban, hiszen az egyes államok szabadon dönthetik el, mely nemzetközi szerződések kötelező hatályát kívánják magukra nézve elfogadni, és melyektöl tekintenek el inkább.

\section{Az élelemhez való jog kikényszeríthetősége(?)}

A Gazdasági, Szociális és Kulturális Jogok Nemzetközi Egyezségokmánya 2. cikke értelmében a részes államok kötelesek a rendelkezésükre álló valamennyi eröforrás igénybevételével és minden megfelelö eszközzel (ideértve különösen a jogszabályi intézkedéseket) az Egyezségokmányban foglalt jogok, így az élelemhez való jog fokozatos biztosítására. A megfelelö eszközök kategóriája azonban ezen második generációs jogok vonatkozásában nem csupán a jogi eszközök alkalmazását jelenti: a gazdasági és szociális jogok előmozdítását segítheti például az államadósság vagy

27 Az iskolatejprogram jogi hátterére vonatkozóan lásd: a Bizottság 657/2008/EK rendelete (2008. július 10.), illetőleg a vidékfejlesztési miniszter 141/2012. (XII. 27.) VM rendelete a 2013. évi óvoda- és iskolatejprogram szabályozásáról.

28 The Right to Food. UNGAA/56/210 on 23 July 2001, 29. pont.

29 Ssenyonjo, Manisuli: Economic, Social and Cultural Rights in International Law. Hart Publishing, $2009,26$. 
az infláció eredményes csökkentése is. ${ }^{30}$ Jóllehet ebböl a megfogalmazásból nem következik az élelemhez való jog azonnali biztosításának kötelezettsége, egyes részelemek tekintetében azonban azonnali intézkedések megtételének kötelezettsége is levezethető, és ezek vonatkozásában akár azok valamely bírói fórum előtti érvényesíthetősége is elképzelhető.

Ilyen azonnali intézkedési kötelezettségnek tekinthető, hogy az államok kötelesek megakadályozni, hogy az élelemhez való hozzáférés tekintetében bármilyen hátrányos megkülönböztetés érvényesüljön egyes társadalmi csoportok vagy személyek között faj, bőrszín, nem, nyelv, vallás, politikai vagy más vélemény, nemzeti vagy társadalmi származás, tulajdon, születés vagy egyéb helyzet alapján. ${ }^{31} \mathrm{~A}$ hátrányos megkülönböztetés tilalma azonban természetszerüleg nem zárja ki, sokkal inkább igényli egyes, különösen hátrányos helyzetű csoportok időleges előnyben részesítését. ${ }^{32}$

Az államok ugyancsak kötelesek lépéseket tenni az élelemhez való jog fokozatos biztosítására - ideértve a megfelelő jogszabályok elfogadását, nemzeti stratégiák kidolgozását vagy éppen a jog érvényesülésének rendszeres figyelemmel követését, illetőleg olyan jogorvoslati lehetőségek biztosítását, melyek alkalmasak az esetleges jogsértésekkel kapcsolatos jóvátételre. Ezen kötelezettség korántsem tekinthető azonban az élelemhez való jog sajátosságának: egy, a jogállamiság elvét és a polgárainak életkörülményeit tiszteletben tartó államnak (politikai rendszerétöl függetlenül) általában is kötelezettsége ezek létrehozatala és müködtetése.

Az államok kötelesek továbbá minden egyes, az Egyezségokmányban foglalt jog tekintetében egy minimális alapvető szint biztosítására, mely az élelemhez való jog vonatkozásában az éhezés és éhínség megakadályozását jelenti, még természeti és egyéb katasztrófák idején is (minimum core obligations). ${ }^{33}$ Talán ez az a kötelezettség, mely a legvitatottabbnak tekinthető: amennyiben elfogadjuk ugyanis, hogy vannak olyan minimumkötelezettségek, amelyek biztosítására az államok minden körülmények között kötelesek, akkor ebböl logikusan következik ezen minimumkövetelmények valamely (belső vagy nemzetközi) fórum előtti érvényesíthetősége is. Ugyan nem az élelemhez való joggal, hanem a megfelelő lakhatással való joggal (majd erre hivatkozással később a vízhez való joggal) ${ }^{34}$ összefüggésben, de a délafrikai alkotmánybíróság pl. kifejezetten elvetette a minimum core obligations koncepcióját ${ }^{35}$ igaz, nem a nemzetközi jogi kötelezettségek, hanem a dél-afrikai alkotmány alapján, és helyette egy ésszerúségi tesztet alkalmazott, mely szerint egy, az adott jog érvényesítését szolgáló állami intézkedés akkor minősíthető jogszerúnek, ha az kiszámítható, arányos és nem zárja ki nagy számban a jogosultakat; az intézkedés

30 SsenYonjo: i. m., 57.

31 A 20. számú Általános Kommentárban (General Comment No. 20., 2009) a Gazdasági, Szociális és Kulturális Jogok Bizottsága részletesen elemzi, mely különbségtételi okok tartozhatnak az „egyéb helyzet” kategóriájába, így különösen a fogyatékosság, életkor, állampolgárság, családi állapot, szexuális orientáció, egészségi állapot, tartózkodási hely, valamint a gazdasági és szociális helyzet.

32 The Right to Adequate Food. Human Rights Fact Sheet No. 34. United Nations, Geneva, 2010, 20.

33 General Comment No. 12., 6. és 17. pontok.

${ }_{34}$ Case CCT 39/09. [2009], Mazibuko, Munyai, Makoatsane, Malekutu and Paki v. City of Johannesburg, Johannesburg Water Ltd. and Minister for Water Affairs and Forestry.

${ }_{35}$ Case CCT 11/00. [2000], Government of the Republic of South Africa and Others v. Grootboom and others. 
az adott jog fokozatos (és nem azonnali) megvalósítását szolgálja; és végezetül, ha tekintettel van a kormányzat számára rendelkezésre álló (elsősorban anyagi) erőforrásokra is. ${ }^{36}$

Az Egyezségokmányban foglalt élelemhez való jog sérelme akkor merülhet fel, ha egy állam nem biztosítja az éhezéstől való mentességhez szükséges minimális feltételeket, ami nem a szükséges mennyiségủ és minőségű élelmiszer előállitásának, hanem sokkal inkább az ehhez szükséges jogszabályi-gazdasági keretek megteremtésének kötelezettségét (ideértve az elosztás megfelelő módon történő biztosítását is) jelenti. Különbség tehető ugyanakkor azon esetek között, amikor az állam fizikailag nem tudja, illetőleg ugyan képes, de valamilyen okból nem hajlandó arra, hogy megfelelő mennyiségü és minőségü élelmet biztosítson. Abban az esetben, ha egy állam bizonyítani tudja, hogy minden lehetséges és ésszerủen elvárható intézkedést megtett a rendelkezésére álló erőforrások megfelelő elosztása érdekében (ideértve például, hogy sikertelenül próbált nemzetközi segítséget szerezni a jog biztosításához), ám így sem tudta az élelemhez való hozzáférést biztosítani azok számára, akik erre saját erejükből képtelenek, emberi jogi jogsértésröl nem beszélhetünk. Abban az esetben azonban, ha az állam képes volna ezen jog biztosítására, ám ezt nem teszi meg, a jogsértés ténye nyilvánvaló. Ez történhet a vonatkozó jogszabályok akár időleges felfüggesztésével vagy megváltoztatásával, a humanitárius élelmiszersegély lakosságtól történő elzárásával (akár annak visszautasítása, akár a céltól eltérő felhasználása miatt), de ugyancsak nyilvánvalóan megengedhetetlen a hátrányos megkülönböztetés tilalmába ütköző módon egyes csoportok hozzáférésének korlátozása is. ${ }^{37}$ Tekintettel arra, hogy a vonatkozó nemzetközi kötelezettség az államot terheli, ekként a magánszektor (ideértve az üzleti szférát is) magatartásáért az állam csupán annyiban tehető felelössé, hogy ezen szereplők magatartásának kereteit az állam jelöli ki a jogalkotási tevékenységével. Egyes radikálisabb nézetek szerint azonban az államok kötelezettsége arra is kiterjed, hogy a joghatóságuk alatt álló valamennyi természetes és jogi személy magatartását akként szabályozzák és ellenőrizzék, hogy azok ne sérthessék meg az élelemhez való jogot más államokban sem.

Bizonyosak lehetünk abban, hogy az élelemhez való jog megsértése nem azonosítható a globális élelmiszerhiánnyal - még abban az esetben sem, ha adott esetben egy országban vagy egy régióban sokak számára nem hozzáférhető egy adott idöszakban a megfelelő élelem. A FAO felmérései szerint napjainkban is kellő mennyiségű és minőségú élelem kerül a Földön megtermelésre a Föld teljes népességének ellátására ${ }^{38}$ - problémát ezen élelmiszer egyenlőtlen hozzáférése jelent.

Az élelemhez való jog biztosítása tekintetében kiemelendő az ENSZ Emberi Jogi Tanácsa alá rendelt, az élelemhez való jog kérdésének különmegbízottja (the Special

36 LARSON, Elizabeth A.: At the Intersection of Neoliberal Development, Scarce Resources, and Human Rights: Enforcing the Right to Water in South Africa. Honors Project, Paper 10., 2010, 74.

37 General Comment No. 12., 17. pont.

38 Lásd például World Hunger and Poverty Facts and Statistics, FAO World Hunger Education Service. Forrás: http://www.worldhunger.org/articles/Learn/world\%20hunger\%20facts\%202002.htm\#Does_the_world_ produce_enough_food_to_feed_everyone (2013. október 28-i letöltés). 
Rapporteur on the Right to Food) munkássága. ${ }^{39}$ A különmegbízott feladatainak teljesítése érdekében éves jelentésben számol be az élelemhez való jog érvényesüléséről az ENSZ Közgyűlésének és az Emberi Jogi Tanácsnak, személyes látogatásokon és a kormányzati tisztviselőkkel és civil szervezetekkel történő találkozásokon alapuló országjelentéseket készít az élelemhez való jog érvényesüléséről, és folyamatosan kommunikálja az érintett kormányok számára az élelemhez való jog feltételezett megsértését, amit akár magánszemélyek vagy csoportok is jelezhetnek számára.

Az élelemhez való jog ENSZ-családon belüli biztosítása tekintetében mindenekelőtt az ENSZ Élelmezésügyi és Mezőgazdasági Világszervezete (FAO) érdemel említést, melynek Alkotmányában is rögzített célja a táplálkozás és életszínvonal emelése; a termelés hatékonysága és az élelemelosztási rendszer javítása; valamint a vidéki lakosság életfeltételeinek jobbítása. A FAO ezen céljait részben az információszolgáltatás, kutatás és figyelemfelhívás, részben pedig technikai segítségnyújtás révén igyekszik elérni. Az ENSZ és a FAO közös Világélelmezési Programja (World Food Programme, WFP) kiemelt célja a krónikus éhezés és alultápláltság elleni globális küzdelem. ${ }^{40}$

Az élelemhez való jog önálló jogként történő felhívására a regionális emberi jogi fórumok előtt nem találunk példát, közvetett módon azonban már több esetben is felmerült a jog sérelme. 2001-ben az Ember és Népek Jogainak Afrikai Bizottsága döntése értelmében a nigériai kormány sértette meg a Niger deltájában élő ogoni nép ezen jogát (az élethez, egészséghez, valamint a gazdasági, szociális és kulturális fejlődéshez való jogból levezetve, hiszen az élelemhez való jog az Emberek és Népek Jogainak Afrikai Egyezményében önállóan nevesítve nem szerepel), ${ }^{41}$ részben amikor semmit nem tett az olajkitermelő társaságok által okozott súlyos környezetszenynyezés megelőzésére és felszámolására, részben pedig amikor ehelyett az elégedetlenkedő helyieket katonai erővel brutálisan elnyomta. ${ }^{42}$ Az Afrikai Bizottság álláspontja szerint az élelemhez való jognak három olyan minimális tartalmi eleme van, melyek a konkrét esetben egyértelmüen sérültek. Egyfelöl az állam köteles annak biztosítására, hogy ne semmisítse meg, illetőleg ne szennyezze az élelem forrásait, másfelől köteles arra, hogy ezt a tevékenységet az államtól független magánvállalkozások számára se engedélyezze, és végezetül nem lehetetlenítheti el a területén élő lakosság önellátásra irányuló próbálkozásait. ${ }^{43}$

2006-ban az Emberi Jogok Amerikaközi Bírósága a sawhoyamaxa törzs élethez való jogának sérelmét állapította meg, miután a paraguayi kormány megfosztotta a törzs tagjait az ősi földjükhöz való hozzáférés lehetőségétől (konkrétan elüzve őket

392008 óta a pozíciót a belga származású Olivier de Schutter tölti be, munkásságáról bővebben lásd: http:// www.ohchr.org/EN/Issues/Food/Pages/FoodIndex.aspx (2013. október 28-i letöltés).

40 A FAO tevékenységének részletes ismertetése meghaladja jelen tanulmány kereteit.

41 Az ügy elemzését lásd például: Coomans, Fons: The Ogoni Case Before The African Commission on Human and Peoples' Rights. International and Comparative Law Quarterly, Vol. 52. (2003) No. 3. 749-760.

42 The Social and Economic Rights Action Center and the Center for Economic and Social Rights v. Nigeria („Ogoni Case”), Communication No. 155/96, Case No. ACHPR/COMM/A044/1 of 27 May 2002., különösen az 56. pont.

43 Lásd a 64-66. pontokat. 
a földjükröl), ami egyben a szükséges minimális élelemhez való hozzáférést is lehetetlenné tette számukra. ${ }^{44} \mathrm{~A}$ Bíróság nem csupán kártérítés megfizetésére kötelezte Paraguayt, hanem egyben arra is, hogy három éven belül minden szükséges intézkedést fogadjon el annak érdekében, hogy a törzs tagjai visszatérhessenek ösi földjükre.

Az Emberi Jogok Európai Bírósága vonatkozó ítélkezési gyakorlatában az élelemhez való jog közvetlen formájában nem hívható fel, hiszen az sem az Emberi Jogok Európai Egyezményében, sem annak kiegészítő jegyzőkönyveiben nem szerepel. Nem zárható ki ugyanakkor elviekben annak lehetősége, hogy az élelemhez való jog sérelmét más, az Egyezményben szereplő jogokkal összefüggésben vizsgálja a Bíróság (így különösen az élethez való jog, a kínzás, embertelen vagy megalázó bánásmód és büntetés tilalma, a magán- és családi élethez való jog, a tulajdonjog jöhet számításba e vonatkozásban), ám tudomásom szerint az élelemhez való hozzáférés kérdései mind ez ideig kizárólag a fogva tartás körülményeivel (és ekként a kínzás tilalma sérelmével) összefüggésben merültek fel a strasbourgi bíróság gyakorlatában, mely esetekben nyilvánvalóan nem egy klasszikusan az élelemhez való jog érvényesíthetőségével kapcsolatos kérdésről, hanem sokkal inkább az eljárás alá vont személyek vallomásának kicsikarása érdekében tett lépésekről volt szó. Álláspontom szerint az a tény, hogy a strasbourgi bíróság (számos esetben rendkívül kreatív és nagy jelentőségű) esetjogából az élelemhez való jog alkalmazására nem hozható példa, elsősorban az európai kontinens gazdasági értelemben vett fejlettségére és ekként a potenciális ügyek hiányára vezethető vissza.

\section{Az élelemhez való jog és más jogok kapcsolata}

Jóllehet az élelemhez való jog meglehetősen kevés nemzetközi emberi jogi dokumentumban szerepel kifejezett formában, a megfelelő élelemhez való jog elválaszthatatlanul összekapcsolódik az élethez és emberi méltósághoz való joggal, hiszen a megfelelő élelemhez történő hozzáférés hiánya nem csupán az emberhez méltó életet, de szélsőséges esetben közvetlenül magát az emberi életet is veszélyeztetheti (illetőleg az élelem fogva tartott személyektől való szándékos megvonása a kínzás, embertelen vagy megalázó bánásmód és büntetés tilalmának sérelmét is megvalósíthatja), és elengedhetetlen más, az Emberi Jogok Nemzetközi Törvényében ${ }^{45}$ biztosított emberi jogok biztosításához. Ugyancsak egyértelmű kapcsolódási pontok mutathatóak ki az élelemhez való jog és a Gazdasági, Szociális és Kulturális Jogok Nemzetközi Egyezségokmányának szintén a 11. cikkében nevesített két további, az Egyezségokmány elfogadása óta eltelt időben önállósuló joggal (ezek a megfelelő lakhatáshoz való jog és a vízhez való jog), hiszen amennyiben valaki nem

44 IACHR, Case of the Sawhoyamaxa Indigenous Community v. Paraguay, Judgment of March 29, 2006 (Merits, Reparations and Costs).

45 Az Emberi Jogok Egyetemes Nyilatkozata, a Polgári és Politikai Jogok Nemzetközi Egyezségokmánya, a Gazdasági, Szociális és Kulturális Jogok Nemzetközi Egyezségokmánya, valamint a Polgári és Politikai Jogok Nemzetközi Egyezségokmánya Első és Második Fakultatív Jegyzőkönyve. 
rendelkezik megfelelő mennyiségű és minőségủ ivóvízhez való hozzáféréssel, illetőleg megfelelő lakással, nagy valószínüséggel arra is képtelen lesz, hogy közvetlenül (főzéssel) vagy közvetett módon (vásárlással) hozzájusson a számára és családja számára szükséges, megfelelö élelemhez.

Az élelemhez való jog szorosan összefügg ugyanakkor az egészséghez való joggal is: az alultápláltság súlyos egészségügyi problémák forrása lehet, különösen a gyermekek, terhes nők és szoptató anyák, kisgyermekek és idősek vonatkozásában. Az alultápláltság vagy éhezés a gyermekek vonatkozásában ezen túlmenően az oktatáshoz való joggal is kapcsolatba hozható - részben azért, mert csökken a gyermek tanulási képessége, részben pedig azért, mert akár a gyermekmunka tilalmának sérelméhez is vezethet, amennyiben a család csak ily módon tudja a szükséges erőforrásokat előteremteni, ami pedig a munkához és szociális biztonsághoz való joggal történő kapcsolódási pontokra mutat rá.

Említést érdemel végezetül az információhoz való joggal történő összefüggések vizsgálata - mely különösen az élelemhez való hozzáférés módja és az élelmiszerbiztonság tekintetében bírhat jelentőséggel. Ebben a megközelítésben például az Európai Unió (és tagállamai) egyre szigorodó, a fogyasztók tájékoztatását a középpontba helyező szabályozási politikája tulajdonképpen az élelemhez való joggal is összefüggésbe hozható.

\section{Az élelemhez való jog a nemzeti jog szintjén}

Az élelemhez való jog biztosítása, a fent vázolt nemzetközi jogi keretek ellenére (vagy éppen ezért) elsődlegesen minden állam saját felelőssége és kötelezettsége, azonban az államok széles mérlegelési jogkörrel rendelkeznek annak meghatározására, hogy milyen módon kívánják ezen jog biztosítását elérni. ${ }^{46}$ Napjainkban mindössze néhány állam alkotmánya tartalmazza önálló jogként a megfelelő élelemhez való jogot - közülük példaként az 1996-ban elfogadott dél-afrikai alkotmány emelhető ki, melynek 27. cikk (1) bekezdése értelmében mindenkinek joga van a megfelelő élelemhez és ivóvízhez való hozzáféréshez ${ }^{47} \mathrm{Az}$ alkotmányok többsége ugyanakkor legfeljebb a megfelelö életkörülményekhez való jog részelemeként említi a megfelelő élelemhez való jog biztosításának kötelezettségét, vagy pedig (az esetek döntő többségében) egyáltalán nem tartalmazza azt. Elfogadható az a megközelítés is, mely a megfelelő élelemhez való jog biztosítását nem is elsősorban jogként, hanem sokkal inkább jogi (jogias) köntösbe bújtatott, és ekként lényegében kikényszeríthetetlen államcélként határozza meg.

Magyarországon az élelemhez való jog kifejezett formájában sem az Alaptörvényből, sem pedig az Alkotmánybíróság határozataiból nem vezethető le. Közvetett mó-

${ }^{46}$ General Comment No. 12., 21. pont.

47 A dél-afrikai alkotmány vonatkozó cikkének kikényszeríthetőségéről szól (igaz, a vízhez való joggal öszszefüggésben) a dél-afrikai alkotmánybíróság elhíresült, ún. Mazibuko-ügyben hozott döntése. Bövebben lásd: SzEMESı Sándor: A Human Right to Water? The Mazibuko Case before the South African Constitutional Court. In: GrekszA Veronika (ed.): Right to Water and the Hungarian Protection of Fundamental Rights. Pécs, Studia Europaea, 2013, 182-191 (megjelenés alatt). 
don azonban az Alaptörvény is elismeri az élelemhez való jogot, részben a testi és lelki egészséghez való jog részeként nevesítve [az Alaptörvény XX. cikk (2) bekezdése értelmében e jog érvényesülését Magyarország egyebek között az egészséges élelmiszerekhez és az ivóvízhez való hozzáférés biztosításával segíti elö], részben pedig a szociális biztonsághoz való jogból (Alaptörvény XIX. cikk) levezethetően. Az Alkotmánybíróság ugyanakkor a 42/2000. (XI. 8.) számú határozatában ${ }^{48}$ úgy foglalt állást, hogy a szociális biztonsághoz való jogból konkrétan meghatározott részjogok és állami kötelezettségek nem vezethetőek le, ekként nagy valószínüséggel az élelemhez való jog hazai bíróságok elötti kikényszerítésére akkor sem kerülhetne sor, ha egyes személyek vagy társadalmi csoportok vonatkozásában ennek elvi lehetösége egyáltalán felmerülne.

\section{Következtetések}

Az élelemhez való jog az élethez és emberi méltósághoz való jog fontos (és egyre növekvő jelentőségü) aspektusát, egyben a Gazdasági, Szociális és Kulturális Jogok Nemzetközi Egyezségokmányából levezethető önálló jogot is jelenti, mely sajátosan átíveli az emberi jogok mindhárom generációját. Jóllehet az élelemhez való jog alapelemei a nemzetközi jogból vezethetőek le, az államokra hárul a döntő szerep a tekintetben, hogy hogyan is lehet a gyakorlatban érvényesíteni ezt a kulcsfontosságú jogosultságot. A nemzetközi jogi keretek között az államok részben a már meglevő jogosultságok védelmére, részben az elért jogvédelmi szint tiszteletben tartására, részben pedig ezen jog fokozatos elömozdítására kötelesek - azonban ezen három kötelezettség gyakorlati megvalósítása döntően a nemzeti jog keretei között történhet. A legtöbb állam alkotmánya nem tartalmazza kifejezetten az élelemhez való jogot, és ahol rögzítették is, ott sem került sor mind ez ideig e jog kikényszeríthetőségének vizsgálatára (bár, a sok tekintetben az élelemhez való joghoz hasonlóan „viselkedő” vízhez való jog érvényesítésére a Dél-afrikai Köztársaságban láttunk már kísérletet az elmúlt években). Ez azonban nem azt jelenti, hogy ezen jog ne töltene be központi szerepet az emberek mindennapjainak életében. Kardos Gábor szavait idézve, enni adni az éhezőknek ma aktuálisabb, mint valaha. ${ }^{49}$

\section{Abstract}

According to the Food and Agriculture Organization of the United Nations (FAO), at least 868 million people are undernourished nowadays. Combating against hunger and malnutrition shall not only be a moral duty, but a legally binding human rights obligation. The right to food is recognized firstly within the text of the Universal Dec-

48 A határozat hivatkozhatóságának alapja a 22/2012. (V. 11.) AB-határozat 40-41. §§, ABH 2012. 2. sz. (2012. június 21.), 97; valamint az ezt megerősítő 13/2013. (VI. 17.) AB-határozat 27-34. §§, ABH 2013. 13. sz. (2013. június 24.), 623.

49 Kardos [2009]: i. m., 119. 
laration of Human Rights adopted in 1948, as part of the right to an adequate standard of living, however nowadays it is considered to be a substantive right. This study deals with the key aspects of the right to adequate food in public international law, including its definition, content and enforcement, as well. 